Prepared in cooperation with the U.S. Department of Energy, National Nuclear Security Administration Nevada Site Office, Office of Environmental Management under Interagency Agreement, DE-A152-07NA28100

\title{
Database of Groundwater Levels and Hydrograph Descriptions for the Nevada Test Site Area, Nye County, Nevada
}

Data Series 533

Version 12.0, April 2022 



\section{Database of Groundwater Levels and Hydrograph Descriptions for the Nevada Test Site Area, Nye County, Nevada}

By Peggy E. Elliott and Joseph M. Fenelon

Prepared in cooperation with the U.S. Department of Energy, National

Nuclear Security Administration Nevada Site Office, Office of Environmental

Management under Interagency Agreement, DE-A152-07NA28100

Data Series 533

Version 12.0, April 2022 


\title{
U.S. Department of the Interior KEN SALAZAR, Secretary
}

\author{
U.S. Geological Survey \\ Marcia K. McNutt, Director
}

\author{
U.S. Geological Survey, Reston, Virginia \\ First release: December 2010 \\ Revised: December 2011 (ver. 2.0) \\ Revised: October 2012 (ver. 3.0) \\ Revised: November 2013 (ver. 4.0) \\ Revised: October 2014 (ver. 5.0) \\ Revised: October 2015 (ver. 6.0) \\ Revised: October 2016 (ver. 7.0) \\ Revised: September 2018 (ver. 8.0) \\ Revised: February 2019 (ver. 9.0) \\ Revised: February 2020 (ver. 10.0) \\ Revised: May 2021 (ver. 11.0) \\ Revised: April 2022 (ver. 12.0)
}

\begin{abstract}
For more information on the USGS - the Federal source for science about the Earth, its natural and living resources, natural hazards, and the environment, visit https://www.usgs.gov or call 1-888-ASK-USGS

For an overview of USGS information products, including maps, imagery, and publications, visit https://www.usgs.gov/pubprod

To order this and other USGS information products, visit https://store.usgs.gov
\end{abstract}

Any use of trade, product, or firm names is for descriptive purposes only and does not imply endorsement by the U.S. Government.

Although this report is in the public domain, permission must be secured from the individual copyright owners to reproduce any copyrighted materials contained within this report.

Suggested citation:

Elliott, P.E., and Fenelon, J.M., 2010, Database of groundwater levels and hydrograph descriptions for the Nevada Test Site area, Nye County, Nevada (ver. 12.0, April 2022): U.S. Geological Survey Data Series 533, 13 p., https://doi.org/10.3133/ds533. 


\section{Contents}

Abstract
Introduction
$\quad$ Purpose and Scope
Description of Study Area
Methods and Data Sources
Rescription of Database

\section{Figures}

1. Map showing areal distribution of wells in the water-level database for the Nevada Test Site area, Nye County, Nevada ......................................................................

2. Diagram showing relationships among data tables in the water-level database for the Nevada Test Site area, Nye County, Nevada ..........................................................11

3. Screen shot showing an example of a worksheet with a hydrograph and well information from the Microsoft ${ }^{\circledR}$ Excel workbook in Elliott and Fenelon (2018, ds533_NTS_hydrographs.xlsx)

\section{Tables}

1. Equations used to correct water levels for borehole deviation in the Nevada Test Site area, Nye County, Nevada.....

2. Descriptions of general and detailed hydrologic conditions assigned to water levels in the Nevada Test Site area, Nye County, Nevada.

3. Descriptions of tables in the water-level database for the Nevada Test Site area, Nye

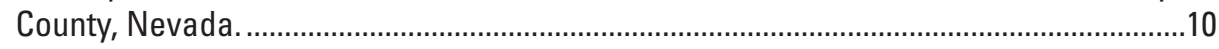




\section{Conversion Factors, Datums, and Acronyms}

Conversion Factors

\begin{tabular}{lll}
\hline \multicolumn{1}{c}{ Multiply } & By & \multicolumn{1}{c}{ To obtain } \\
\hline inch (in.) & 2.54 & centimeter $(\mathrm{cm})$ \\
foot (ft) & 0.3048 & meter $(\mathrm{m})$ \\
mile (mi) & 1.609 & kilometer $(\mathrm{km})$ \\
foot squared per day $\left(\mathrm{ft}^{2} / \mathrm{d}\right)$ & 0.09290 & meter squared per day $\left(\mathrm{m}^{2} / \mathrm{d}\right)$ \\
\hline
\end{tabular}

Transmissivity: The standard unit for transmissivity is cubic foot per day per square foot times foot of aquifer thickness $\left[\left(\mathrm{ft}^{3} / \mathrm{d}\right) / \mathrm{ft}^{2}\right] \mathrm{ft}$. In this report, the mathematically reduced form, foot squared per day $\left(\mathrm{ft}^{2} / \mathrm{d}\right)$, is used for convenience.

Datums

Vertical coordinate information is referenced to the National Geodetic Vertical Datum of 1929 (NGVD 29).

Horizontal coordinate information is referenced to the North American Datum of 1983 (NAD 83) unless otherwise stated.

Altitude, as used in this report, refers to distance above the vertical datum.

Acronyms

DOE U.S. Department of Energy

NTS Nevada Test Site

NWIS National Water Information System

USGS U.S. Geological Survey 


\title{
Database of Groundwater Levels and Hydrograph Descriptions for the Nevada Test Site Area, Nye County, Nevada
}

\author{
By Peggy E. Elliott and Joseph M. Fenelon
}

\begin{abstract}
A database containing water levels measured from wells in and near areas of underground nuclear testing at the Nevada Test Site since 1941 was developed. The database provides information for each well including well construction, borehole lithology, units contributing water to the well, and general site remarks. Water-level information provided in the database includes measurement source, status, method, accuracy, and specific water-level remarks. Additionally, the database provides hydrograph narratives that document the water-level history and describe and interpret the water-level hydrograph for each well.

Water levels in the database were quality assured and analyzed. Multiple conditions were assigned to each water-level measurement to describe the hydrologic conditions at the time of measurement. General quality, temporal variability, regional significance, and hydrologic conditions are attributed to each water-level measurement.
\end{abstract}

\section{Introduction}

The Nevada Test Site (NTS; currently called the Nevada National Security Site) is in Nye County, southern Nevada (fig. 1), about 65 mi northwest of Las Vegas, Nevada. From 1951 to 1992,828 underground nuclear tests were completed at the NTS (U.S. Department of Energy, 2000). Most of the tests were done in five areas: Pahute Mesa, Rainier Mesa, Yucca Flat, Shoshone Mountain, and Frenchman Flat (Laczniak and others, 1996, fig. 2; U.S. Department of Energy, 2000, p. xviii; Wills, 2008, p. 14-1). All underground tests at Yucca Flat, Frenchman Flat, and Pahute Mesa were conducted in vertical shafts drilled into alluvial and volcanic rock, and in a few cases into carbonate and granitic rock. Nearly all tests at Rainier Mesa and Shoshone Mountain were conducted in tunnel complexes mined into low-permeability, zeolitized tuff (National Security Technologies, LLC, 2007).

The U.S. Department of Energy (DOE), National Nuclear Security Administration Nevada Site Office, under its Environmental Restoration Program, has a long-term program to investigate and remediate radionuclide contaminants generated on the NTS as a result of nuclear testing. As part of the program, DOE is evaluating what risk these contaminants may pose to the public. To help accomplish this objective, groundwater levels are being compiled and analyzed to better understand the groundwater flow system in areas of underground nuclear testing.

\section{Purpose and Scope}

This report documents and describes a comprehensive collection of water-level measurements made in and near areas of underground nuclear testing on the NTS since 1941. The water-level measurements and descriptions are stored in a Microsoft ${ }^{\circledR}$ Access database.

The process to develop the groundwater-level database (hereinafter water-level database) involved several steps. First, water-level measurements from wells in the study area and supporting information from various data sources were compiled and merged into the database. The supporting information, for use in interpreting the water-level measurements, includes site characteristics, well-construction information, lithologic logs, and contributing units for each well. Second, each water-level measurement was assigned multiple attributes to describe the hydrologic condition at the time of measurement. Third, a narrative was written for each well that provides information and comments about the well, water-level data for the well, and possible causes of water-level fluctuations. 


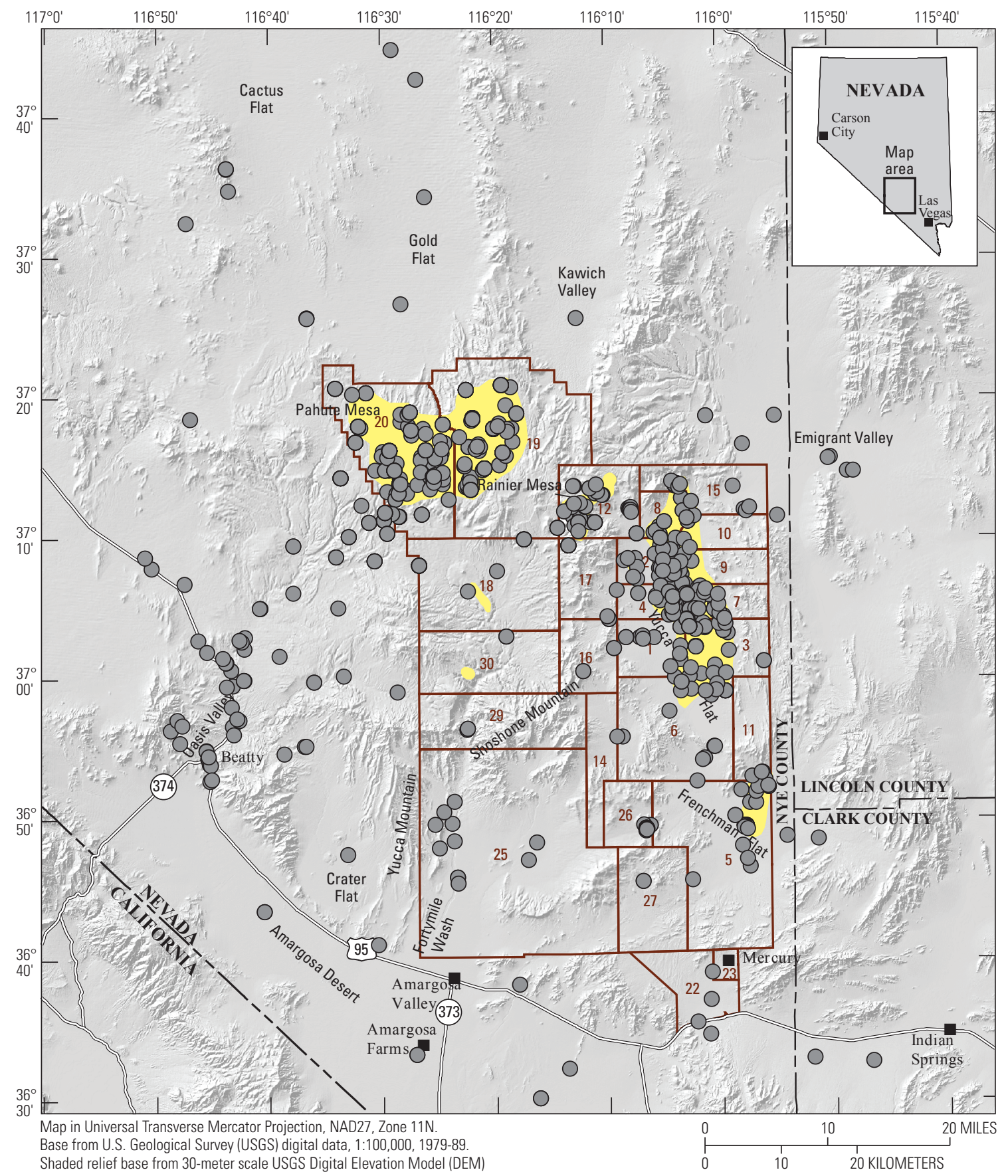

EXPLANATION

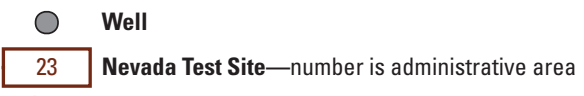

Area of underground nuclear testing—modified from Laczniak and others (1996)

Figure 1. Areal distribution of wells in the water-level database for the Nevada Test Site area, Nye County, Nevada. 
Water-level measurements, site characteristics, and wellconstruction information contained in the water-level database were obtained from the U.S. Geological Survey (USGS) National Water Information System (NWIS) database (U.S. Geological Survey, 2010a), available at http://waterdata.usgs. gov/nv/nwis/ (hereinafter NWIS database). Prior to merging the NWIS data into the water-level database, a systematic quality-assurance review of data stored in the NWIS database and USGS data files in Henderson, Nev. for the wells was completed. Erroneous water-level data or duplicate sites were removed from or corrected in the NWIS database, and additional water-level measurements and site and construction information obtained from the data files were added to the NWIS database. Well-construction data were compiled from driller's logs, well completion reports, and other published and unpublished information. Lithologic data were obtained mostly from Wood (2007), but also from well completion reports and other published and unpublished information. Units contributing water to the wells were modified after Fenelon and others (2010).

This report is the fifth in a series of studies by the USGS, in cooperation with DOE, to review NWIS data for quality assurance, add additional data previously missing from the NWIS database, and interpret historic water-level measurements in and near areas of underground nuclear testing on the NTS (Bright and others, 2001; Fenelon, 2000, $2005,2006)$. This report updates water-level data published in previous reports, adds data from many additional wells, and compiles all available water-level data from underground test areas into a single database.

\section{Description of Study Area}

The study area includes the NTS and surrounding area, and incorporates areas of past underground nuclear testing on the NTS (fig. 1). The topography of the NTS includes volcanic highlands, such as Pahute and Rainier Mesas, and surrounding alluvial-filled basins. Altitudes in the study area range from about 2,300 to $8,500 \mathrm{ft}$.

The climate of the study area is arid to semiarid. Annual precipitation ranges from less than $5 \mathrm{in}$. on the lowest valley floors to about 13 in. in the highest upland areas (Soulé, 2006). Precipitation falls primarily as rain, and as snow at higher altitudes during the winter months. Streams in the study area are ephemeral and flow only for brief periods after infrequent, intense rainfall and during and soon after spring snowmelt.

The geology of the NTS and surrounding area is stratigraphically and structurally complex (Winograd and Thordarson, 1975; Laczniak and others, 1996; Slate and others, 1999). Volcanic rocks dominate well completions in Pahute and Rainier Mesas, the Cactus Range, and some parts of Yucca, Frenchman, and Jackass Flats. The volcanic rocks predominantly consist of aquifers composed of welded ash-flow tuffs and lavas, and confining units composed of bedded air-fall and nonwelded ash-flow tuffs. Alluvial basin fill and carbonate rocks also are common in well completions, and typically are aquifers. Alluvial fill is penetrated in some well completions, primarily in Yucca and Frenchman Flats, Emigrant and Oasis Valleys, Gold Flat, and Amargosa Desert. Carbonate rocks typically lie beneath the alluvial and volcanic rocks and most commonly are intersected by wells in Yucca Flat where the depth to the top of carbonate rock is not excessive. A few wells in the study area are completed in sedimentary clastic rock and granite, which typically are confining units.

Aquifers at the NTS have been mapped as alluvial-volcanic or carbonate, based on lithology and hydraulic connection (Fenelon and others, 2010). These aquifers have been further classified as (1) "regional" if they form continuous flow systems connecting areas of recharge with areas of discharge, or (2) "local" if they are isolated by confining units and flow predominately as vertical leakage into the adjacent confining units.

\section{Groundwater-Level Database}

The USGS collects and maintains water-level data for wells on and near the NTS (U.S. Geological Survey, 2010b, at http://nevada.usgs.gov/doe nv). As part of this data-collection program, current and historic water-level data are compiled, reviewed, and stored in the NWIS database. The water-level database in this report contains water-level measurements retrieved from the NWIS database for wells throughout the study area. Water-level data for these wells have been collected periodically since 1941 .

Water-level data contained in the water-level database were collected from boreholes with single or multiple completions, or from measurement sites in mine shafts or tunnel complexes. As used in this report, the term "well" was chosen to represent a single, temporary or permanent completion in a borehole, where each completion defines a discrete open interval; a site used to measure depth to water in a flooded mine shaft; or a site in a tunnel used for measuring impounded tunnel water. Examples of multiple "well completions" in a single borehole may include (1) multiple temporary packed intervals, where each packed interval is considered a well completion, (2) multiple monitoring tubes or piezometers installed within the annulus of a main well completion, and (3) an open borehole that is monitored during a break in drilling (considered to be an initial well completion, as defined in this report) and then later deepened and completed (the only actual well completion in the borehole, but considered a second well completion in this report). 
A unique site identification number and site name were established in the NWIS database for each well. A "well," as used in this report, is referred to as a "site" in the NWIS database. Well and site are interchangeable in this report. All well names in this report are derived from the NWIS database.

Naming conventions for "wells" in the water-level database are as follows. The first part of a well name is the USGS borehole name [Elliott and Fenelon (2018), ds533_NTS_WL.accdb (referred to as appendix A in previous versions), Well_Characteristics_Summary]; official NTS hole numbers also are provided in Well_Characteristics_Summary. If a well completion represents the sole or final completion interval in a borehole, the entire well name typically is identical to the USGS borehole name-for example: well $U E-1 a$ (well names in this report are italicized). In boreholes with multiple completions, well names typically are differentiated from each other by a parenthetical expression added after the borehole name-for example: well UE-2aa $(2207 \mathrm{ft})$. A single number in the parenthetical expression refers to the depth of the well; two numbers separated by a dash refer to the depth of the top and bottom of the open interval in the well. In some cases, a well name consists of the borehole name and a non-parenthetical expression (main, piezometer) that follows the borehole name.

\section{Methods and Data Sources}

The water-level database in this report provides site information for each well, water-level and well-construction data, borehole lithology, units contributing water to the well, and information on the external conditions influencing each water level measured in the study area (Elliott and Fenelon, 2018, ds533_NTS_WL.accdb). Information in the water-level database was derived from datasets created for this study and datasets available from the NWIS database. Boreholelithologic descriptions were obtained mostly from Wood (2007) and designation of units contributing water to the wells were modified after the subsurface hydrologic unit types described in Fenelon and others (2010).

A systematic quality-assurance review of site information and water-level data in the NWIS database for wells in the study area, and for data not previously published in Bright and others (2001) and Fenelon (2000, 2005, 2006) was completed for this study. This review included removing or correcting duplicate sites or erroneous water-level data in the NWIS database, and adding water-level measurements and site and construction information obtained from USGS data files stored in Henderson, Nev. that were previously missing from the NWIS database. A summary of water-level measurements for the wells is shown in Elliott and Fenelon (2018, ds533_NTS WL.accdb, Water_Level_Measurements_Summary).
Periodic water-level measurements in the water-level database primarily were made by USGS or private contracting agencies working at the NTS using a calibrated electric tape, calibrated electric-cable unit (also known as iron-horse and wire-line device), and less commonly, a steel tape, fluiddensity geophysical log, airline, float recorder, pressure transducer, and pressure gage. Most water-level measurements prior to 1996 were made with an electric-cable unit (Garber and Koopman, 1968), whereas more recent measurements typically were made using an electric tape. Electric tapes are calibrated annually at different water-level depths with a USGS steel reference tape. At the time of measurement, a correction factor is applied to the depth-to-water reading based on the annual calibration. Post-1995 measurements using electric tapes generally are more accurate $( \pm 0.1 \mathrm{ft})$ than older measurements using electric-cable units or other methods $( \pm 0.5-2 \mathrm{ft})$.

Water-level measurements collected from wells in boreholes that deviated from vertical during drilling were corrected for borehole deviation (table 1). As a general rule, water levels are corrected for borehole deviation if the correction is greater than $1.0 \mathrm{ft}$. Corrections less than $1.0 \mathrm{ft}$ were not applied to water levels because at depths exceeding $1,000 \mathrm{ft}$ for water levels in many wells on the NTS the uncertainty in the deviation correction can be as great or greater than the magnitude of the correction. Exceptions to this rule exist for some wells where the borehole deviation equations were developed under other water-level measurement programs. Water levels in these boreholes were corrected for borehole deviation although the corrections are less than $1 \mathrm{ft}$.

The equations used to calculate water-level corrections for borehole deviation are based on the source of information available, such as a drilling report or well diagram that reported the slant angle of the borehole or a borehole-deviation survey. When only the slant angle of the borehole is available, the angle of deviation along the measured depth interval is assumed constant and the correction equation is derived as follows:

$$
V_{d}=M_{d} * \cos \theta,
$$

where

$V_{d}$ is corrected vertical water-level depth, in feet below land surface;

$M_{d}$ is measured water-level depth, in feet below land surface;

$\theta$ is angle of slant from the vertical. 
Table 1. Equations used to correct water levels for borehole deviation in the Nevada Test Site area, Nye County, Nevada.

USGS borehole name: USGS borehole name as shown in Elliott and Fenelon (2018,ds533_NTS_WL.accdb, Well_Characteristics_Summary). Names in bold are boreholes intentionally drilled at a slant angle. Equation used to derive borehole deviation equation: Borehole deviation equations were derived using equations (1) and (2), which are described in the "Groundwater-Level Database" section of the report. Depth interval over which correction applies: Measured depth interval that bounds the minimum and maximum depths of historic water-level measurements. The depth interval is used in equation (2) to derive the borehole deviation equation. Borehole deviation equation used to correct water levels: $V_{d}$, corrected vertical water-level depth; $M_{d}$, measured water-level depth along slant hole. Average water-level adjustment: Average amount of adjustment subtracted from measured water level $\left(M_{d}\right)$ to obtain corrected vertical water level $\left(\mathrm{V}_{\mathrm{d}}\right) ;-$, no adjustment applied.

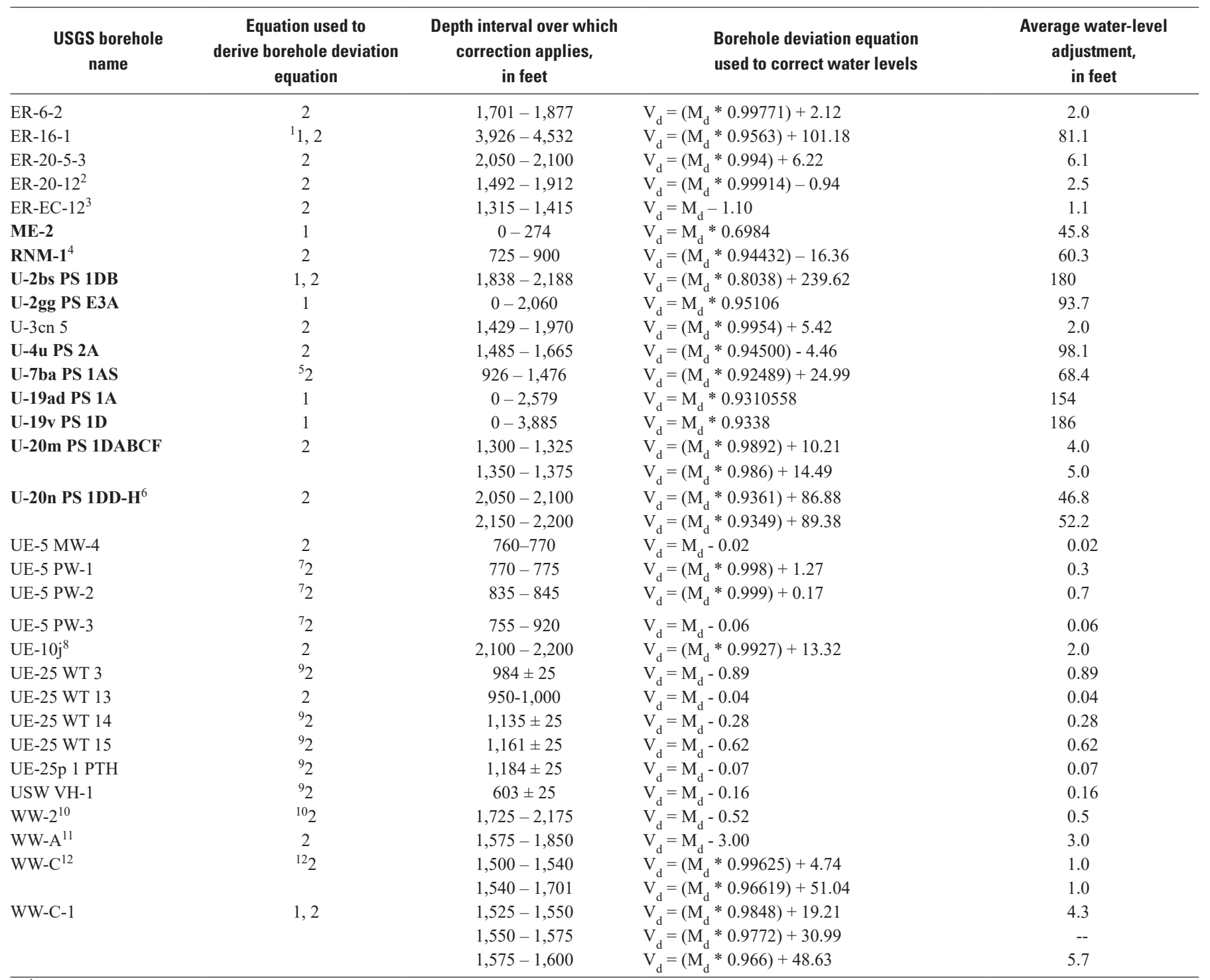

\footnotetext{
${ }^{1}$ Source of data includes a borehole deviation survey completed to a depth of 3,926 ft, and an assumed constant angle of slant to 4,172 $\mathrm{ft}$ (bottom of borehole). The slant angle is based on the measured deviation at a depth of $3,926 \mathrm{ft}$.

${ }^{2}$ Includes wells ER-20-12 m1; ER-20-12 p1; ER-20-12 p2; ER-20-12 p3; and ER-20-12 p4.

${ }^{3}$ Includes wells ER-EC-12 main (upper zone), ER-EC-12 deep, ER-EC-12 intermediate, and ER-EC-12 shallow.

${ }^{4}$ Includes wells RNM-1, RNM-1 (Zone I perfs), RNM-1 (Zone IV perfs), and RNM-1 (Zone V perfs).

${ }^{5}$ Sporadic borehole-deviation measurements were obtained from drilling records.

${ }^{6}$ Includes wells $U$-20n PS $1 D D-H$ (3025 ft), U-20n PS IDD-H (4309 ft), and U-20n PS IDD-H (4470 ft).

${ }^{7}$ Borehole deviation information from National Security Technologies, LLC, 2011.

${ }^{8}$ Includes wells $U E-10 j(2232-2613 \mathrm{ft}), U E-10 j(2232-2297 \mathrm{ft})$, and $U E-10 j(2380 \mathrm{ft})$.

${ }^{9}$ Borehole deviation information from Savard, 2001.

${ }^{10}$ Includes wells $W W-2(2045 \mathrm{ft}), W W-2(2535 \mathrm{ft}), W W-2(2896 \mathrm{ft}), W W-2(3422 \mathrm{ft})$, and $W W-2(3422 \mathrm{ft}$, uncased). Borehole deviation information from Moore and others, 1963.

${ }^{11}$ Includes wells $W W-A(1730 \mathrm{ft})$ and $W W-A(1870 \mathrm{ft})$.

${ }^{12}$ Includes wells $W W-C(1373-1701 \mathrm{ft}$ ) and $W W-C$ (recompleted). Source of data includes a borehole deviation survey completed to a depth of $1,540 \mathrm{ft}$, and an assumed constant angle of slant to $1,701 \mathrm{ft}$ (bottom of borehole). The slant angle is based on the measured deviation at a depth of 1,540 ft.
} 
When a borehole-deviation survey is available, water-level corrections for selected depth intervals are developed based on cumulative measured borehole deviations from the survey. The true vertical water-level depth for a selected depth interval is determined by using a linear equation of the form:

$$
V_{d}=\left(M_{d}-M_{t o p}\right) *\left(\Delta V_{i n t} / \Delta M_{i n t}\right)+V_{t o p},
$$

where

$$
\begin{array}{cc}
V_{d} \quad \begin{array}{l}
\text { is corrected vertical water-level depth, in feet } \\
\text { below land surface; }
\end{array} \\
M_{d} \quad \begin{array}{c}
\text { is measured water-level depth, in feet below } \\
\text { land surface; }
\end{array} \\
\begin{array}{c}
M_{\text {top }} \quad \begin{array}{l}
\text { is measured depth to top of depth interval over } \\
\text { which correction applies, in feet below land }
\end{array} \\
\text { surface; }
\end{array} \\
\Delta V_{\text {int }} \quad \begin{array}{l}
\text { is difference in true vertical depths between } \\
\text { top and bottom of depth interval over which }
\end{array} \\
\text { correction applies, in feet below land surface; } \\
\Delta M_{\text {int }} \quad \begin{array}{l}
\text { is difference in measured depths between top } \\
\text { and bottom of depth interval over which }
\end{array} \\
\quad \begin{array}{l}
\text { correction applies, in feet below land surface; } \\
\text { and }
\end{array} \\
\quad \begin{array}{l}
\text { is true vertical depth to top of depth interval } \\
\text { over which correction applies, in feet below } \\
\text { land surface. }
\end{array}
\end{array}
$$

As an example, a borehole deviation survey for borehole UE-10j (USGS data files, Henderson, Nev.) shows that a measured depth interval of 2,100-2,200 ft below land surface can be used to bound historic water-level measurements for well completions in this borehole (table 1). The corresponding true-vertical depths from the deviation survey at the top and bottom of this interval are 2,097.99 and 2,197.26 ft, respectively. Substituting these values into equation 2 gives the linear water-level adjustment for the depth interval that bounds historic water levels:

$$
V_{d}=\left(M_{d}-2,100\right) *(99.27 / 100.00)+2,097.99
$$

In reduced form, equation 3 becomes:

$$
V_{d}=\left(M_{d} * 0.9927\right)+13.32
$$

Water levels in 51 wells in 31 boreholes in the study area were corrected for borehole deviation (table 1). Ten of these boreholes are slant holes that were intentionally drilled at an angle. The average water-level adjustments for borehole deviation in the slant holes and in borehole ER-16-1 are greater than $45 \mathrm{ft}$, with the exception of borehole U-20m PS $1 \mathrm{DABCF}$. In the remaining boreholes, the average water-level adjustments were less than about $6 \mathrm{ft}$.

Hydrologic conditions were used to describe the state of each water level that was measured in the study area. The conditions also describe the external factors that may have affected the measured depths-to-water. Hydrologic conditions were categorized as either general or detailed (table 2). General hydrologic conditions describe the state of a water level; examples are steady state, transient, and nonstatic. Detailed hydrologic conditions describe the effect that a factor may have on a water level, or denote the uncertainty of a water-level interpretation. Factors affecting water levels include pumping, recent well construction, and earthquake response. Water-level effects include abrupt change, equilibration, and rising trend. One general hydrologic condition and as many as six detailed hydrologic conditions were assigned to each water-level measurement in the study area.

The contributing units assigned to each well in the study area were based on subsurface hydrologic unit types as described in Fenelon and others (2010). A contributing unit represents the hydrologic unit at the open interval of the well that may contribute water to the well. A well may have been assigned more than one contributing unit code if multiple units are encountered by the open interval. All contributing unit codes are defined in Elliott and Fenelon (2018) in the Excel workbook named ds533_NTS_hydrographs.xlsx.

The water-level history of each well is documented in a hydrograph narrative. The narrative consists of comments or explanations about the well or water-level data measured in the well. An interpretation of the hydrograph and its hydrologic significance also is provided for most wells as part of the narrative. The narrative may include information about the open interval, testing done in the well, well productivity, specific influences near the well that may have affected water levels, and other details that may provide additional information about the conditions affecting past water-level measurements in the well. Basic information included in the narratives was derived from published reports or from USGS data files stored in Henderson, Nev. 
Table 2. Descriptions of general and detailed hydrologic conditions assigned to water levels in the Nevada Test Site area, Nye County, Nevada.

\begin{tabular}{|c|c|}
\hline Condition name & Description \\
\hline Insufficient data & Water level does not have sufficient supporting information to determine its general condition. \\
\hline Localized conditions & $\begin{array}{l}\text { Water level represents non-steady hydrologic conditions in a small part of the aquifer directly adjacent to the } \\
\text { well; water level is affected by activities near or in the well such as a nuclear test or small-scale pumping. }\end{array}$ \\
\hline None & $\begin{array}{l}\text { No water level was recorded because well is dry or obstructed, or site was visited but water level was not } \\
\text { measured. }\end{array}$ \\
\hline Nonstatic & $\begin{array}{l}\text { Water level represents non-steady hydrologic conditions in the well that are not representative of the } \\
\text { surrounding aquifer; water level is affected by activities in the well, such as aquifer testing, well } \\
\text { construction, or pumping. }\end{array}$ \\
\hline Steady state & $\begin{array}{l}\text { Water level approximates pre-development, steady-state hydrologic conditions in the groundwater flow system. } \\
\text { The flow system can be fully saturated or perched. Water level is in dynamic equilibrium and considered to } \\
\text { be steady state relative to long-term (50-100 years) climatic conditions. Water-level changes occurring as a } \\
\text { result of natural conditions are considered steady state. }\end{array}$ \\
\hline Suspect & Water level is suspect or in error, and cannot be attributed to any known hydrologic cause. \\
\hline Transient & $\begin{array}{l}\text { Water level represents non-steady hydrologic conditions in the groundwater flow system that typically result } \\
\text { from pumping in the well or a nearby well. The flow system can be fully saturated or perched. }\end{array}$ \\
\hline \multicolumn{2}{|r|}{ Detailed condition } \\
\hline Abrupt change & Water level rapidly shifted or changed from previous measurement. \\
\hline Anomalous - high & Water-level altitude is unusually high relative to other measurements in the well or in nearby wells. \\
\hline Anomalous - low & Water-level altitude is unusually low relative to other measurements in the well or in nearby wells. \\
\hline Borehole deviation & Water level is corrected for borehole deviation. \\
\hline Consistent & $\begin{array}{l}\text { Water level appears to be part of a reasonably consistent trend representative of general water-level conditions } \\
\text { in the area. }\end{array}$ \\
\hline Declining trend & $\begin{array}{l}\text { Water level appears to be part of a discernible, overall downward trend. Possible causes include nearby } \\
\text { pumping, decreased recharge, equilibration following drilling, or depressurization after a nuclear test. }\end{array}$ \\
\hline Destroyed & Well was destroyed; no water-level measurement was made. \\
\hline Dry & No water level was recorded because well was dry at time of measurement. \\
\hline Earthquake response & Water level appears to be responding to a recent earthquake. \\
\hline Elevated & $\begin{array}{l}\text { Water level is appreciably elevated relative to representative levels in the adjacent groundwater flow system. } \\
\text { Elevated level is believed to result from naturally occurring, large vertical gradients in the area of the well. } \\
\text { Representative levels in the adjacent flow system are based on Fenelon and others (2010) and Fenelon and } \\
\text { others (2012). }\end{array}$ \\
\hline Equilibration & $\begin{array}{l}\text { Water level appears to be part of a discernible, overall trend that is approaching an equilibrium level, either } \\
\text { higher or lower than the current measurement. Equilibration commonly occurs following well construction, } \\
\text { pumping, or nearby nuclear testing. }\end{array}$ \\
\hline Erratic/Unstable & Water level is erratic and unstable. \\
\hline Evapotranspiration response & Water level appears to be responding to evapotranspiration. \\
\hline Floating oil & $\begin{array}{l}\text { Water-level measurement may be affected by floating oil in the well. Reported measurement is not corrected for } \\
\text { variable density effects. }\end{array}$ \\
\hline Injection recovery & Water level is equilibrating from an injection of water, mud, or other fluid into the well or hole. \\
\hline Limited data & Water level is one of a limited number. Therefore, the general condition assigned to water level is tentative. \\
\hline Local infiltration & $\begin{array}{l}\text { Water level is responding to infiltration from a locally derived source of water, such as a nearby pond or stream } \\
\text { channel. }\end{array}$ \\
\hline
\end{tabular}


Table 2. Descriptions of general and detailed hydrologic conditions assigned to water levels in the Nevada Test Site area, Nye County, Nevada.-Continued.






\section{Description of Database}

The water-level database in Elliott and Fenelon (2018, ds533_NTS_WL.accdb, referred to as appendix A in previous versions) is comprised of 16 tables. Site, well-construction, and lithology information for the wells in the study area are stored in 9 tables, and water-level information, including water-level data, hydrologic conditions at the time of each water-level measurement, and a hydrograph narrative for each well are contained in 4 tables (table 3). A summary of selected well characteristics and water-level information retrieved from these tables is presented in 2 additional tables in the database: Well_Characteristics_Summary and Water_Level_ Measurements_Summary (Elliott and Fenelon, 2018).

The structure of the water-level database is shown in figure 2. Tables in the database are linked by the field USGS site_no (USGS site number), a unique 15-digit number used to identify each well; three tables also are linked by the field Water_level_date_time (water-level date and time). An effort was made to maintain a database structure that is similar to the structure of the NWIS database outlined in U.S. Geological Survey (2005). For example, the five construction tables from the NWIS database are preserved in the water-level database.

Hydrographs and well locations in the study area are interactively presented in a Microsoft ${ }^{\circledR}$ Excel workbook in Elliott and Fenelon (2018, ds533_NTS_hydrographs.xlsx). The workbook is designed to be an easy-to-use tool to obtain the water-level history for any well in the study area. It also can be used to filter water-level data by restricting the data to certain wells, dates, or hydrologic conditions. Figure 3 is an example of a worksheet from the workbook and shows well ER-2-1 piezometer (deep), which was selected with the pull-down list using the Microsoft ${ }^{\circledR}$ Excel built-in AutoFilter. Selected site information, water-level information and conditions, and the contributing unit from the water-level database are shown for this well. Additional information provided includes a short narrative that describes the well and hydrograph, and a hyperlink to the NWISWeb site home page for the well.

Information for each water level shown in the example in figure 3 , and for all water levels in the water-level database, includes water-level source, status, method, and accuracy (which pertains to the depth-to-water measurement and not the water-level altitude), and hydrologic conditions at the time of the water-level measurement. Interpretations for individual water-level measurements and for the period of record for a well have been incorporated into the water-level remark, hydrologic conditions, or hydrograph narrative (fig. 3). Abrupt water-level changes and long-term waterlevel declines are examples of typical hydrologic conditions that were interpreted. The components of the water-level record, including those shown in figure 3 , are defined in table NTS14_field_descriptions in the water-level database in Elliott and Fenelon (2018, ds533_NTS_WL.accdb). Revisions made during the previous year to water-level data, general hydrologic-condition flags, or major changes to hydrograph narratives, are documented in table NTS16_revision_history in the water-level database. 
Table 3. Descriptions of tables in the water-level database for the Nevada Test Site area, Nye County, Nevada.

[NA, not applicable]

\begin{tabular}{|c|c|c|c|}
\hline Table name & Table grouping & Type of data & Remarks \\
\hline NTS03_hole & Construction record & Hole diameter and interval & $\begin{array}{l}\text { May have multiple entries for each well } \\
\text { that describe unique intervals of the } \\
\text { hole }\end{array}$ \\
\hline NTS05_opening & Construction record & $\begin{array}{l}\text { Open-interval diameter, interval, } \\
\text { material, type, and size of opening }\end{array}$ & $\begin{array}{l}\text { May have multiple entries for each well } \\
\text { that describe unique open intervals of } \\
\text { the hole and/or casing }\end{array}$ \\
\hline NTS06_measuring_point & Construction record & $\begin{array}{l}\text { Information about stable points } \\
\text { on or near a well from which } \\
\text { measurements of depth-to-water are } \\
\text { made }\end{array}$ & $\begin{array}{l}\text { Populated with wells actively or recently } \\
\text { measured by USGS }\end{array}$ \\
\hline NTS08_water_levels_gen_cond & Water-level record & $\begin{array}{l}\text { General hydrologic condition } \\
\text { at the time of the water-level } \\
\text { measurement }\end{array}$ & \\
\hline NTS09_water_levels_det_cond & Water-level record & $\begin{array}{l}\text { Detailed hydrologic conditions at the } \\
\text { time of the water-level measurement } \\
\text { that describe water-level trends, } \\
\text { factors causing changes in water } \\
\text { levels, or uncertainty of a water- } \\
\text { level interpretation }\end{array}$ & \\
\hline NTS10_hydrograph_narrative & Water-level record & $\begin{array}{l}\text { The hydrograph narrative documents } \\
\text { the water-level history of each well } \\
\text { including comments or explanations } \\
\text { about the well, hydrograph, or } \\
\text { specific water levels }\end{array}$ & \\
\hline NTS13_aquifer & Geohydrologic record & $\begin{array}{l}\text { Aquifer(s) or lithologic unit(s) } \\
\text { contributing water to well }\end{array}$ & $\begin{array}{l}\text { The designations for aquifers or water- } \\
\text { bearing units are modified after the } \\
\text { subsurface hydrologic unit types } \\
\text { described in figure } 3 \text { and appendix } 3 \\
\text { of Fenelon and others (2010) }\end{array}$ \\
\hline NTS14_field_descriptions & NA & $\begin{array}{l}\text { Metadata for database tables NTS01- } \\
\text { NTS13 }\end{array}$ & $\begin{array}{l}\text { Descriptions of the components in each } \\
\text { database table }\end{array}$ \\
\hline NTS15_references & NA & $\begin{array}{l}\text { References cited in the NTS10 } \\
\text { hydrograph_narrative table }\end{array}$ & \\
\hline NTS16_revision_history & NA & $\begin{array}{l}\text { Documentation of revisions to water- } \\
\text { level data, general condition flags, } \\
\text { and major changes to hydrograph } \\
\text { narratives }\end{array}$ & $\begin{array}{l}\text { Revision history began with database } \\
\text { updates in Data Series 533, version } \\
\text { 4.0, November } 2013\end{array}$ \\
\hline
\end{tabular}



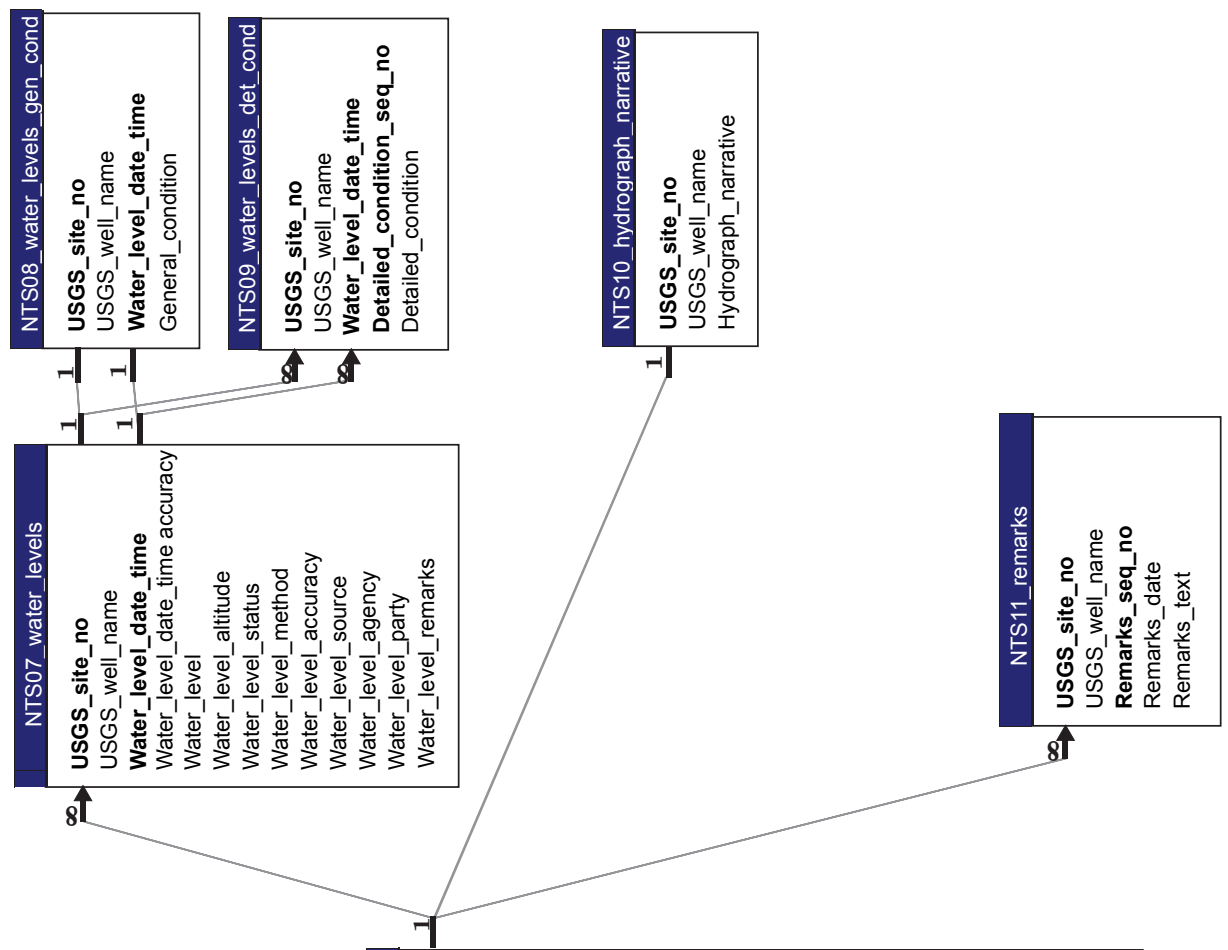

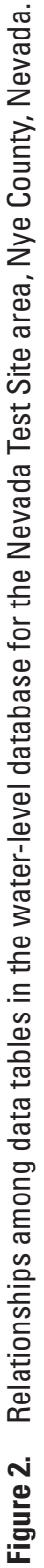






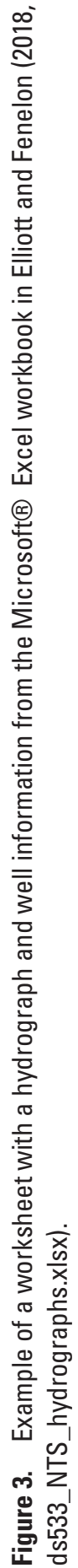




\section{Acknowledgments}

This study was prepared in cooperation with the U.S. Department of Energy under Interagency Agreement DE-A152-07NA28100. The authors wish to extend their appreciation to all who participated in data collection over many years, which has resulted in the abundance of data included in this report and associated database. Special thanks to Randell Laczniak (U.S. Geological Survey, retired) who was always there to discuss the meaning of a water level.

\section{References Cited}

Bright, D.J., Watkins, S.A., and Lisle, B.A., 2001, Analysis of water levels in the Frenchman Flat area, Nevada Test Site: U.S. Geological Survey Water-Resources Investigations Report 00-4272, $43 \mathrm{p}$.

Elliott, P.E., and Fenelon, J.M., 2018, Database of groundwater levels and hydrograph descriptions for the Nevada Test Site area, Nye County, Nevada (ver. 5.0, February 2022): U.S. Geological Survey data release, https://doi.org/10.5066/ F75H7FGN.

Fenelon, J.M., 2000, Quality assurance and analysis of water levels in wells on Pahute Mesa and vicinity, Nevada Test Site, Nye County, Nevada: U.S. Geological Survey Water-Resources Investigations Report 00-4014, 68 p.

Fenelon, J.M., 2005, Analysis of ground-water levels and associated trends in Yucca Flat, Nevada Test Site, Nye County, Nevada, 1951-2003: U.S. Geological Survey Scientific Investigations Report 2005- 5175, 87 p.

Fenelon, J.M., 2006, Database of ground-water levels in the vicinity of Rainier Mesa, Nevada Test Site, Nye County, Nevada, 1957-2005: U.S. Geological Survey Data Series 190, version 1.10, October 2007, $14 \mathrm{p}$.

Fenelon, J.M., Sweetkind, D.S., and Laczniak, R.J., 2010, Groundwater flow systems at the Nevada Test Site, Nevada-A synthesis of potentiometric contours, hydrostratigraphy, and geologic structures: U.S. Geological Survey Professional Paper $1771,53 \mathrm{p}$.

Fenelon, J.M., Sweetkind, D.S., Elliott, P.E., and Laczniak, R.J., 2012, Conceptualization of the predevelopment groundwater flow system and transient water-level responses in Yucca Flat, Nevada National Security Site, Nevada: U.S. Geological Survey Scientific Investigations Report 2012-5196, 61 p.

Garber, M.S., and Koopman, F.C., 1968, Methods of measuring water levels in deep wells: U.S. Geological Survey Techniques of Water-Resources Investigations, chap. A1, book 8, 23 p.

Laczniak, R.J., Cole, J.C., Sawyer, D.A., and Trudeau, D.A., 1996, Summary of hydrogeologic controls on ground-water flow at the Nevada Test Site, Nye County, Nevada: U.S. Geological Survey Water-Resources Investigations Report 96-4109, 59 p.
Moore, J.E., Doyle, A.C., Walker, G.E., and Young, R.A., 1963, Ground water Test Well 2, Nevada Test Site, Nye County, Nevada: U.S. Geological Survey Open-File Report 63-101, $73 \mathrm{p}$.

National Security Technologies, LLC, 2007, A hydrostratigraphic model and alternatives for the groundwater flow and contaminant transport model of corrective action unit 99Rainier Mesa-Shoshone Mountain, Nye County, Nevada: U.S. Department of Energy Report DOE/NV/25946-146 [variously paged].

National Security Technologies, LLC, 2011, Nevada National Security Site 2010 Data Report-Groundwater monitoring program, Area 5 Radioactive Waste Management Site: U.S. Department of Energy Report DOE/NV/25946-1133, [variously paged].

Savard, C.S., 2001, Water levels in the Yucca Mountain area, Nevada: U.S. Geological Survey Open-File Report 01-343, $81 \mathrm{p}$.

Slate, J.L., Berry, M.E., Rowley, P.D., Fridrich, C.J., Morgan, K.S., Workman, J.B., Young, O.D., Dixon, G.L., Williams, V.S., McKee, E.H., Ponce, D.A., Hildenbrand, T.G., Swadley, W.C., Lundstrom, S.C., Ekren, E.B., Warren, R.G., Cole, J.C., Fleck, R.J., Lanphere, M.A., Sawyer, D.A., Minor, S.A., Grunwald, D.J., Laczniak, R.J., Menges, C.M., Yount, J.C., and Jayko, A.S., 1999, Digital geologic map of the Nevada Test Site and vicinity, Nye, Lincoln, and Clark Counties, Nevada, and Inyo County, California: U.S. Geological Survey OpenFile Report 99-554-A, 54 p.

Soulé, D.A., 2006, Climatology of the Nevada Test Site: National Oceanic and Atmospheric Administration Air Resources Laboratory Technical Memorandum SORD 2006-3, 165 p.

U.S. Department of Energy, 2000, United States nuclear tests, July 1945 through September 1992: U. S. Department of Energy Nevada Operations Office, DOE/NV-209-REV 15, $162 \mathrm{p}$.

U.S. Geological Survey, 2005, User's manual for the National Water Information System of the U.S. Geological SurveyGround-Water Site-Inventory System: U.S. Geological Survey Open-File Report 2005-1251, version 4.4, 274 p.

U.S. Geological Survey (2010a) National Water Information System-USGS Water Data for Nevada: U.S. Geological Survey database, accessed July 20, 2010, at http://waterdata. usgs.gov/nv/nwis/.

U.S. Geological Survey (2010b) USGS/U.S. Department of Energy Cooperative Studies in Nevada: U.S. Geological Survey website, accessed July 20, 2010, at http://nevada.usgs. gov/doe nv/.

Winograd, I.J., and Thordarson, William, 1975, Hydrogeologic and hydrochemical framework, south-central Great Basin, Nevada-California, with special reference to the Nevada Test Site: U.S. Geological Survey Professional Paper 712-C, 126 p.

Wills, C.A., 2008, ed., Nevada Test Site environmental report 2007: National Security Technologies, LLC, DOE/NV/25946543 [variously paged].

Wood, D.B., 2007, Digitally available interval-specific rocksample data compiled from historical records, Nevada Test Site and vicinity, Nye County, Nevada: U.S. Geological Survey Data Series 297, rev. 2.00, 58 p. 
Publishing support provided by the U.S. Geological Survey

Science Publishing Network, Tacoma Publishing Service Center

For more information concerning the research in this report, contact the Director, Nevada Water Science Center

U.S. Geological Survey

2730 N. Deer Run Road

Carson City, Nevada 89701

https://www.usgs.gov/centers/nv-water 


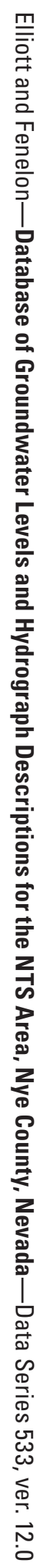

